\title{
The Effect of for Group Empowerment for Reducing Depression in Elderly
}

\author{
Kartinah Kartinah $^{1 *} \mathbb{D}$, Sumarni Sumarni ${ }^{2}$ \\ ${ }^{1}$ Department of Community and Family, Faculty of Health, University Muhammadiyah of Surakarta, Surakarta, Indonesia; \\ ${ }^{2}$ Department of Psychiatry, Faculty of Medicine, Gadjah Mada University, Yogyakarta, Indonesia
}

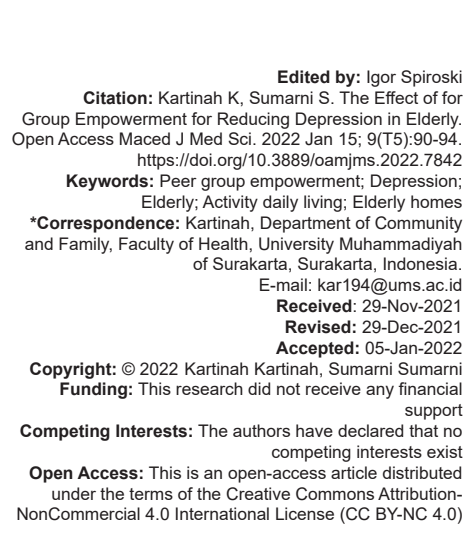

\section{Introduction}

Indonesia is a country that has entered the era of an aging structured population, as has happened in other countries in the world. For this reason, the World Health Organization [1] invites to make aging an important priority. The number of elderly Indonesians in 2011 was 20 million people $(9.51 \%)$ with a life expectancy of 67.4 years and continues to increase so that it is estimated to be 28.8 million people (11.34\%) in 2020 (Depkes RI, 2012) [2].

When a person enters old age, problems in the form of physical, psychological, and social setbacks will occur. This physical setback can lead to various chronic diseases, degenerative diseases, and metabolic diseases (diabetes, hypertension, hyperlipidemia, and hyperthyroidism). The ability to adapt psychologically is low, resulting in the emergence of mental problems in the form of depression. According to the Maslim (2012) in Sumarni (2014) [3], metabolic syndrome and degenerative diseases will increase mental disorders. On the other hand, mental disorders such as depression can exacerbate degenerative diseases and metabolic syndrome.

Depression is an emotional condition that is generally characterized by extreme sadness, feelings of meaninglessness and guilt, withdrawal from others, disturbed sleep patterns, loss of appetite, sexual desire, and interest and pleasure in usual activities (Davidson et al. 2010) [4]. Feelings of guilt or sin, useless, and hopeless in people with depression can lead to suicide or suicidal behavior (lyus, 2007) [5].

This study aimed to determine the effect of peer group empowerment (PGE) in reducing depression in the active elderly at the Dharma Bhakti Social Home Surakarta.

\section{Methods}

This type of research was quantitative with a quasi-experimental pre- and post-test with control group 
research method with the intervention of implementing PGE in fulfilling passive elderly activity daily living (ADL). The research sample was determined using purposive sampling consisting of 22 people as the intervention group and 22 people as the control group with inclusion criteria: (1) Clients with a tendency to mild-to-severe depressive disorder but still able to communicate well, (2) willing to be respondents and following the research procedure until the final stage, (3) able to communicate verbally, and (4) have a level of independence with Category A index category. The exclusion criteria were the elderly who did not participate in the activity until it was finished $A$. The intervention group was treated with the application of PGE for 2 weeks, and then, a posttest of depression level was conducted using a geriatric depression scale questionnaire. Wilcoxon test analysis was used in this study. The results of the analysis showed a significant change in the level of depression in the intervention group.

\section{Results}

This research was conducted at Panti Wredha Dharma Bhakti Surakarta. Primary data were obtained through observation and interviews. Obtained research subjects as many as 44 people with the characteristics of the respondents are shown in Table 1.

Table 1: Distribution of respondent characteristics

\begin{tabular}{|c|c|c|c|c|}
\hline \multirow[t]{2}{*}{ Characteristics Respondent } & \multicolumn{2}{|c|}{ Intervention Group } & \multicolumn{2}{|c|}{ Control group } \\
\hline & $n=22$ & $\%$ & $n=22$ & $\%$ \\
\hline \multicolumn{5}{|l|}{ Age } \\
\hline 60-74 years old (elderly) & 15 & 68 & 11 & 50 \\
\hline 75-90 years old (old) & 7 & 32 & 11 & 50 \\
\hline \multicolumn{5}{|l|}{ Gender } \\
\hline Men & 11 & 50 & 9 & 41 \\
\hline Woman & 11 & 50 & 13 & 59 \\
\hline \multicolumn{5}{|l|}{ Marital status } \\
\hline Not married & 8 & 36 & 5 & 23 \\
\hline Widow widower & 14 & 64 & 17 & 77 \\
\hline \multicolumn{5}{|l|}{ Last education } \\
\hline Not completed in primary school & 12 & 55 & 17 & 77 \\
\hline Primary school & 6 & 27 & 3 & 13 \\
\hline Middle school & 3 & 14 & 1 & 5 \\
\hline High school & 1 & 4 & 1 & 5 \\
\hline \multicolumn{5}{|l|}{ Work before at the orphanage } \\
\hline Labor & 15 & 68 & 16 & 73 \\
\hline Entrepreneur/trade & 5 & 23 & 6 & 27 \\
\hline Etc. & 2 & 9 & & \\
\hline \multicolumn{5}{|l|}{ Length of stay in the orphanage } \\
\hline$<1$ year old & 9 & 41 & 6 & 27 \\
\hline $1-3$ years & 9 & 41 & 8 & 36 \\
\hline $3-5$ years old & 1 & 4 & 3 & 14 \\
\hline$>5$ years old & 3 & 14 & 5 & 23 \\
\hline
\end{tabular}

The age of the respondents in the intervention group and the control group was in the range between 60 and 74 years (elderly) and between the ages of 75 and 90 years (old). In the intervention group, the majority were in the elderly range $(68 \%)$ and for the control group the percentages were balanced, each of which was $50 \%$.

The sex of the respondents in the intervention group was balanced by $50 \%$ each, while in the control group the majority were women, namely, $59 \%$.
The marital status of the respondents was mostly widows/widowers, namely, in the intervention group by $64 \%$ and in the control group by $77 \%$. Apart from widow/widower status, some of the other respondents said that they had never been married and none of the respondents had married status.

The majority of respondents' education was that they did not graduate from elementary school (elementary school), namely, 55\% in the intervention group and $77 \%$ in the control group. The highest education taken by the respondents was at the high school level.

The Most of the respondents had a job before living in an orphanage as laborers, namely, 68\% in the intervention group and $73 \%$ in the control group. Another occupation of the elderly is entrepreneurship in the form of trading. There were two elderly people in the intervention group who worked as buskers. The length of stay in the nursing home for the intervention group was mostly <1 year and between 1 and 3 years, each was $41 \%$, while for the control group, the majority was in the range of $1-3$ years, namely, $36 \%$.

Based on Table 2, the result of measuring the level of depression before the implementation of PGE mainly was in the mild category, namely, $55 \%$ in the intervention group and $73 \%$ in the control group.

Table 2: Distribution of respondents by level of depression before peer group empowerment was implemented

\begin{tabular}{llllll}
\hline Depression level & \multicolumn{2}{l}{ Kelp Intervention } & & & Kelp Control \\
\cline { 2 - 3 } \cline { 6 - 6 } & $\mathrm{N}$ & & & $\mathrm{n}$ & $\%$ \\
\hline Mid & 12 & 55 & & 16 & 73 \\
Moderate & 10 & 45 & & 5 & 23 \\
Severe & 0 & 0 & & 1 & 4 \\
Total & 22 & 100 & & 22 & 100 \\
\hline
\end{tabular}

Table 3 shows that the assistance with the highest frequency was in eating/drinking activities in the form of fetching, feeding and tidying up equipment, defecate, and urinate activities are limited to getting the bedpan and this is the activity that is rarely done because the elderly, both passive and active, say they feel safer and more comfortable when assisted by officers.

Table 3: Types and frequency of passive elderly ADL fulfillment assistance by the intervention group after the application of PGE

\begin{tabular}{lllllll}
\hline \multirow{2}{*}{ Team } & \multicolumn{2}{l}{ Help Type } & & Amount \\
\cline { 2 - 5 } & Bath & Dress & Defecate/pee & Move & Eat/drink & \\
\hline 1 & 10 & 2 & 3 & 16 & 30 & 61 \\
2 & 9 & 3 & 2 & 17 & 32 & 63 \\
3 & 15 & 12 & 4 & 18 & 41 & 90 \\
4 & 8 & 3 & 4 & 15 & 21 & 51 \\
5 & 7 & 5 & 3 & 14 & 22 & 51 \\
6 & 2 & 2 & 0 & 14 & 24 & 42 \\
7 & 4 & 4 & 0 & 20 & 12 & 40 \\
8 & 5 & 5 & 2 & 13 & 12 & 37 \\
9 & 7 & 7 & 3 & 22 & 14 & 53 \\
10 & 9 & 9 & 3 & 14 & 10 & 45 \\
11 & 6 & 6 & 4 & 15 & 10 & 41 \\
Total & 82 & 58 & 28 & 178 & 228 & 574 \\
$\%$ & 14.3 & 10.1 & 4.9 & 31 & 39.7 & 100 \\
\hline ADL: Activity daily living, PGE: Peer group empowerment. & \multicolumn{7}{l}{}
\end{tabular}

Table 4 shows the level of depression after being given the intervention in the intervention and control groups. In intervention group there were $91 \%$ 
Table 4: Distribution of respondents by level of depression after the implementation of peer group empowerment

\begin{tabular}{llllll}
\hline Depression level & \multicolumn{2}{l}{ Intervention group } & & & \multicolumn{2}{c}{ Control group } \\
\cline { 2 - 3 } & $\mathrm{n}$ & $\%$ & & $\mathrm{~N}$ & $\%$ \\
\hline Light & 20 & 91 & & 15 & 68 \\
Medium & 2 & 9 & & 5 & 23 \\
Weight & 0 & 0 & & 2 & 9 \\
Total & 22 & 100 & & 22 & 100 \\
\hline
\end{tabular}

in the mild category and $9 \%$ in the moderate category. Meanwhile, in the control group, the post-test results were $68 \%$ in the mild category, $23 \%$ in the moderate category, and $9 \%$ in the severe category.

Table 5 shows the results of the Wilcoxon test calculation, which obtained a Z-value of -3.937 with $p=0.000$ for the intervention group $(p<0.05)$, which means that there is a significant difference between the depression level values between the pre-test and post-test in the intervention group. In the control group, the Z-value was -0.074 with $p=0.941(p>0.05)$, which means there is no difference between the depression scores in the pre-test and post-test. Therefore, empirically, it can be concluded that there is a decrease in elderly depression with the application of PEG.

Table 5: Wilcoxon test results on pre-test and post-test scores for depression levels in the intervention group and the control group

\begin{tabular}{lllll}
\hline Group & Test & Average & Z-value & p-value in Wilcoxon's test \\
\hline Intervention & Pre-test & 8.95 & -3.937 & 0.000 \\
& Post-test & 5.95 & & \\
Control & Pre-test & 8.09 & -0.074 & 0.941 \\
& Post-test & 8.23 & & \\
& & & &
\end{tabular}

\section{Discussion}

The results showed that the most of the respondents before the intervention had mild depression, namely, $55 \%$ in the intervention group and $73 \%$ in the control group. The remaining $45 \%$ in the intervention group and $23 \%$ in the control group experienced moderate depression and only one person or $4 \%$ in the control group had a tendency to experience severe depression but were still able to carry out daily activities independently. Purbowinoto's research (2011) [6] at the Budi Luhur Nursing Home in Yogyakarta also showed the same percentage of depression in the elderly, namely, $77.8 \%$ experiencing mild depression and $22.2 \%$ experiencing moderate depression. Wulandari's research (2011) comparing the incidence of depression in the elderly in nursing homes with the elderly in the community found that the percentage of depression in the elderly in the nursing home was actually lower $(38.5 \%)$ when compared to the elderly in the community $(60 \%)$ [15]. This may be due to the fact that the elderly in the orphanage can interact more often with fellow elderly (peers) and also the orphanage staff so that this becomes a meaningful social support for the elderly. The same thing was expressed by Tresnawati's research (2012) [7] regarding the pattern of interaction between fellow elderly and the elderly with nursing home staff at Minaula Kendari nursing home which showed that good social interaction with fellow elderly and nursing home staff considered as a substitute for the family will have a positive influence on aspects of the life of the elderly, especially the psychological aspect. PGE is carried out after the active elderly, both the intervention group and the control group are given education regarding the fulfillment of ADL needs in the form of bathing, dressing, elimination or urination/defecation, changing places, and eating/drinking, and how to provide assistance to the passive elderly safely. Participants said that so far they rarely help friends who are passive because they are not asked and the needs of the passive elderly have been helped by the orphanage staff.

The routine activities of the elderly who are not crowded show that the elderly's free time is not used properly. According to the Erlangga's research (2010) [8], there are several problems that are often experienced by the elderly living in orphanages including loneliness, alienation from the environment, helplessness, dependence, and lack of confidence, neglect, especially for the poor elderly. It can eliminate happiness, desire, hope, peace of mind, the ability to feel the serenity of life, and affect the occurrence of depression. The elderly who are often unemployed and not involved in activities while they are actually still able to participate will cause a sense of powerlessness, decreased self-confidence, desires and hopes, and happiness of the elderly.

Suardiman (2011) [9] said that efforts to overcome depression include doing activities that bring pleasure, doing daily activities and avoiding long free time, developing positive thoughts about oneself as a useful person, and communicating with others for support and stimulants.

The application of PGE allows active elderly to make efforts to overcome depression as stated by Suardiman. When the elderly in the intervention group carried out activities to help fulfill the passive elderly $A D L$, then he had carried out daily activities and avoided long free time. Active seniors can also develop positive thoughts about themselves because they feel useful by helping passive elderly people and feel more fortunate because they still have the ability to be independent in terms of ADL and in the end get a sense of pleasure. Feelings of pleasure and satisfaction as an expression that he has the ability to give something can raise self-esteem and self-confidence which are important aspects for one's psychological health.

PGE is carried out in teams (groups) so that it provides opportunities for active and passive elderly in the team to interact or communicate with each other. When communicating with fellow elderly, there will be an exchange of information, sharing stories, 
and experiences. According to the Hurlock (1993) in Suardiman (2011), establishing communication between fellow elderly is also one of the developmental tasks of the elderly. If the developmental task can be carried out properly, it will bring happiness; otherwise it will bring unhappiness and will hinder the next developmental task.

The results of the Wilcoxon test calculation obtained a Z-value of -3.937 with $p=0.000$ for the intervention group. This shows that the difference in depression scores between the pre-test and posttest in the intervention group is significant. Therefore, empirically, it can be concluded that there is a decrease in elderly depression with the application of PGE. The condition of the elderly living in orphanages with low socio-economic and educational backgrounds and the absence of a family often create negative thoughts in the elderly. The physical, psychological, and social changes occur result in feelings of worthlessness. This is what encourages the emergence of depression nursing problems related to low self-esteem (NANDA, 2012) [10]. PGE provides an opportunity for the elderly to be useful by helping fellow elderly so that they can increase their self-confidence as well as their selfesteem so that positive thoughts arise. These results are in accordance with the research of Prasetya et al. (2010) [11] which states that cognitive therapy is proven to reduce depression. Cognitive therapy can change negative thoughts that affect mood and tend to cause depression. These negative thoughts are in the form of feeling helpless, unappreciated, feeling no one loves, not excited, feeling alone, afraid of illness and death, and others. In line with Susanti's research, the involvement and activity of the elderly in the PGE program are expected to change the negative aspects into positive aspects and increase the self-esteem of the elderly as the aspects of self-esteem proposed by Coopersmith in Kuswardani and Risa research (2009) [12] are (1) self-significance, (2) individual strength (power), (3) competence, and (4) individual obedience and the ability to set an example. According to the Shearer (2009) [13], the objectives of health empowerment are facilitate recognition and build capacity, support social interaction, and facilitate the use of social services. This is very useful for preventing depression.

Research by Pfeiffer et al. (2011) [14] found that peer support intervention can help reduce symptoms of depression. There are several concepts that explain why peer support can be beneficial for depressed patients, namely, it can directly reduce the level of isolation, reduce the impact of stressors (buffering effect), increase opportunities for exchanging health information, and as positive role modeling.

Observations on the implementation of PGE conducted by researchers also found that there were special things outside the research objectives but interesting to discuss because of the possibility of a connection with depression in the elderly. The special thing is that the finding of a special relationship shown by two pairs of elderly people of different sexes. This special relationship can be seen from the intense interaction and willingness to serve each other in several ADL activities.

According to the Suardiman (2011), interpersonal interest in the elderly can occur due to four factors, namely, physical closeness, positive emotions, observable characteristics, and need for affiliation. If these four factors occur in the interaction between the elderly, then there will be an expression of mutual liking through words and actions.

Maharani's research (2013) on interpersonal attraction of the opposite sex in the nursing home of Pengsti Lawang found that the type of love that occurs in the elderly in the orphanage shows companionate love because it looks like a component of intimacy and commitment and empty love because it only shows a commitment component that dominates more than intimacy and passion. While the type of love passion (excitement) was not found, Feeling loved, cared for, and cared for by family or friends are an important aspect of one's psychological health. This is also what may happen to the two elderly couples and the form of the relationship they are currently living can be a form of social support.

The advantage of this research is that respondents benefit from being able to increase their self-actualization by helping their fellow elderly, while for the elderly who experience limited activity, it can be helped to fulfill their daily needs. The weakness of this study is the risk of injury to the elderly if not supervised by the nursing home staff

\section{Conclusion}

Peer group empowerment effects the decrease of depression in the elderly in elderly homes Dharma Bhakti of Surakarta.

\section{References}

1. World Health Organization; 2012. Available from: https://www google.com/search?q=prevalensi+lansia+menurt+who\&ie=utf8\&oe=utf-8\&aq=t\&rls=org.mozilla:en-US:official\&client=firefoxa \&channel=fflb [Last accessed on 2021 May 25].

2. Depkes RI. Profil Kesehatan Indonesia 2001. Jakarta: Depkes $\mathrm{RI} ; 2002$.

3. Sumarni S. Modul Penanggulangan Depresi Lansia Secara Sosial dan Spiritual. Jogyakarta: Bagian kedokteran Jiwa Fakultas Kedokteran Universitas Gadjah Mada; 2014. https:// doi.org/10.19087/jveteriner.2016.17.1.7 
4. Davidson GC, Neale JM, Kring AM. Psikologi Abnormal. Jakarta: Rajawali Press; 2010.

5. Yosep I. Keperawatan Jiwa, PT Refika Aditama: Bandung; 2007.

6. Purbowinoto SE. Pengaruh Terapi Musik Keroncong terhadap Perubahan Tingkat Depresi pada Lansia di PSTW Budi Luhur Yogyakarta; 2011. Available from: http://www.eprints.ums. ac.id/39510/ii/naskah\%20publikasi.pdf [Last accessed on 2016 Nov 12]. https://doi.org/10.21927/jnki.2013.1(2).37-42

7. Tresnawati SE. Pola Interaksi Antar Sesama Lansia dan Lansia Dengan Petugas di PSTW; 2012. Available from: http://www. minaulauho.ac.id/skripsi.php?read=1246 [Last accessed on 2016 Nov 14].

8. Erlangga SW. Subyjecktive Well-Being Pada Lansia Penghuni Panti Jompo; 2010. Available from: http://www.publication. gunadarma.ac.id [Last accessed on 2016 Nov12].

9. Suardiman SP. Psikologi Lanjut Usia. Yogyakarta: Gajah Mada University Press; 2011.

10. NANDA. Nursing Diagnosis: Definition and Classification.
Philadelphia, PA, USA: NANDA; 2012.

11. Prasetya AS, Hamid AY, Susanti H. Penurunan tingkat depres klien lansia dengan terapi kognitifdan senam latih otak di panti wredha. J Keperawatan Indones. 2010;13(1):1-7. https://doi. org/10.7454/jki.v13i1.230

12. Kuswardani I, Risa P. Hubungan Antara Harga Diri dan Prestasi Belajar Fisika Siswa STM. Surakarta: Universitas Setya Budi; 2009. https://doi.org/10.23887/jjpf.v10i1.26714

13. Shearer NB. Health empowerment theory as a guide for practice. Geriatr Nurs. 2009;30 Suppl 2:4-10. https://doi.org/10.1016/j. gerinurse.2009.02.003 PMid:19345857

14. Pfeiffer PN, Heisler M, Piette JD, Rogers MA, Valenstein M. Efficacy of peer support interventions for depression: A metaanalysis. Gen Hosp Psychiatry. 2011;33(1):29-36. https://doi. org/10.1016/j.genhosppsych.2010.10.002

PMid:21353125

15. Wulandari. (2011). Kejadian dan Tingkat Depresi pada Lanjut

Author Queries???

AQ1: Kindly provide complete reference. 